American Journal of Infectious Diseases 5 (2): 90-98, 2009

ISSN 1553-6203

(C) 2009 Science Publications

\title{
Cytotoxic and Antimicrobial Potential of Actinomycete Species Saccharopolyspora salina VITSDK4 Isolated from the Bay of Bengal Coast of India
}

\author{
K. Suthindhiran and K. Kannabiran \\ School of Biotechnology, Chemical and Biomedical Engineering, \\ Vellore Institute of Technology University, Vellore, Tamil Nadu, India
}

\begin{abstract}
Problem statement: Although the diversity of marine Actinobacteria have been studied and biotechnologically exploited throughout the world, the studies on marine actinobacteria in Indian peninsula are largely unexplored. Of 9 maritime states in India, only 4 states have been extensively studied for the diversity of actinobacteria. Further, the studies on bioactive actinomycetes from saline soil are very scanty. In the present study, we had taken an initiative to isolate culturable halophilic actinomycetes and to screen the bioactive potential. Approach: The marine sediment sample was collected at a depth of $400 \mathrm{~cm}$ at Marakkanam. The strain was isolated using ISP No. 2 medium supplemented with $25 \%$ sea water. The polyphasic taxonomy of the strain was evaluated by phenotypic, chemotaxonomic and phylogenetic analysis. The 16S rRNA was sequenced and phylogenetic relationship with the closest related species were studied. The growth conditions and the medium had been optimized under shake-flask conditions by measuring the dry weight of the mycelium. The isolate was subjected to fermentation and the crude extract was screened for cytotoxic, hemolytic and antimicrobial activity. The cytotoxicity was evaluated on HeLa cells by MTT assay, hemolytic assay on mouse erythrocytes and the antimicrobial activity was determined by agar diffusion assay. Results: Based on polyphasic taxonomy the species was identified as Saccharopolyspora salina and belongs to the genus Saccharopolyspora. The 16S rRNA sequence of the isolate showed 100\% similarity with Saccharopolyspora salina. Based on the phylogenetic and phenotypic evaluation the isolate was designated as Saccharopolyspora salina VITSDK4. The growth was maximal in the designed production medium with the incubation temperature of $28^{\circ} \mathrm{C}$ and $\mathrm{pH}$ of 7.4. It is a moderately halophilic species requires $9 \% \mathrm{NaCl}$ concentration for optimal growth. The cytotoxicity on HeLa cells showed the $\mathrm{IC}_{50}$ value of $26.2 \mu \mathrm{g} \mathrm{mL}^{-1}$ by MTT assay. The hemolytic activity on mouse erythrocytes showed the $\mathrm{EC}_{50}$ value of $266 \mu \mathrm{g} \mathrm{mL} \mathrm{L}^{-1}$. The crude extract also exhibited significant antagonistic activity against fungal pathogens Aspergillus niger, Aspergillus fumigatus, Candida albicans and the Gram negative bacteria Escherichia coli and Klebsiella pneumoniae. Only moderate activity was seen against Gram positive bacteria Staphylococcus aureus and Bacillus subtilis. Conclusion/Recommendations: Based on the results of our investigation, the isolated strain was identified as Saccharopolyspora salina VITSDK4, which was moderately halophilic, produces an extracellular bioactive metabolite, which inhibits the proliferation of HeLa cells as well as antagonistic to fungal and bacterial pathogens. Further studies on purification and characterization of the pure compound from the strain were ongoing. The results of this study suggested that the marine actinomycetes from the unexplored Indian coast could provide lead compounds of therapeutic value.
\end{abstract}

Key words: Marine actinomycetes, Saccharopolyspora salina VITSDK4, halophilic, cytotoxic, antimicrobial

\section{INTRODUCTION}

Marine microorganisms continue to provide pharmacologically important secondary metabolites which are unique and novel chemical compounds.
Marine microbes are continuously explored for drug discovery. Apart from microbes all other marine sources have also provided valuable chemical diversity ${ }^{[1]}$. Marine actinomycetes have been traditionally a rich source for biologically active

Corresponding Author: K. Kannabiran, Biomolecules and Genetics Division, School of Biotechnology, Chemical and Biomedical Engineering, VIT University, Vellore-632014, Tamil Nadu, India Tel: +91-416-2202473 Fax: +91-416- 2243092 / 2240411 
metabolites. Although heavily studied over the past three decades, actinomycetes continue to prove themselves as reliable sources of novel bioactive compounds. Among the well-characterized pharmaceutically relevant microorganisms, actinomycetes remain major sources of novel, therapeutically relevant natural products ${ }^{[2]}$. The majority of these compounds demonstrate one or more bioactivities many of them developed into drugs for treatment of wide range of diseases in human, veterinary and agriculture sectors ${ }^{[3]}$. Searching for novel actinomycetes constitutes an essential component in natural product-based drug discovery. Analytical methods continue to improve to allow the rapid elucidation of structures and make natural products valuable components of modern drug discovery.

The isolated compounds from marine actinomycetes has a broad spectrum of biological activities such as antibiotic, antifungal, toxic, cytotoxic, neurotoxic, antimitotic, antiviral and antineoplastic activities $^{[4]}$. Recently, new targets have been added to the general screening like AIDS, immunosuppression, anti-inflammation, Alzheimer disease, ageing processes, some tropical diseases and resulted in discovery of several drugs ${ }^{[5]}$ Studies on marine actinomycetes are facing some unexpected problems. For many of the marine actinomycetes the taxonomy of the strain is very poorly defined, so that binomial identifications are frequently uneasy to be carried out.

The genera Saccharopolyspora belongs to the class actinobacteria and the order Actinomycetales. The genus Saccharopolyspora belongs to the family Pseudonocardiaceae, is known for producing antibiotics such as vancomycin, erythromycin and rifamycins $^{[6]}$. The genus Saccharopolyspora was proposed by ${ }^{[7]}$ originally isolated from spontaneously heated sugarcane bagasse. Representatives of these species form a distinct phyletic line within the evolutionary radiation encompassed by the family Pseudonocardiaceae can be distinguished by using phenotypic properties ${ }^{[8]}$.

Members of the genus Saccharopolyspora are characterized by aerobic, extensively branched substrate hyphae that fragment into rod-shaped elements and aerial hyphae that segment into bead-like chains of spores. The colonies are thin, raised, slightly wrinkled and mucoid in appearance. The cell wall envelope is rich in iso- and anteiso branched chain fatty acids, wall chemotype IV; do not contain mycolic acids, MK-9 $\left(\mathrm{H}_{4}\right)$ as predominant menaquinone and DNA G+C contents in the range of $66-77 \mathrm{~mol}^{[9]}$. Members of the genus Saccharopolyspora are a potentially rich source of natural products, but only erythromycin, produced by
Saccharopolyspora erythraea, is of commercial importance ${ }^{[10]}$. The isolation of the genus Saccharopolyspora is complicated because of the poor knowledge of its habitation and slow growth. In this study, we report a polyphasic taxonomic study of Saccharopolyspora salina VITSDK4 isolated from a saltpan marine soil sample collected at the Marakkanam coast and its cytotoxic, hemolytic and antimicrobial activity.

\section{MATERIALS AND METHODS}

Sampling and isolation of actinomycetes: The marine sediment samples collected at the depth of $400 \mathrm{~cm}$ in the Marakkanam, [Latitude (N) 12 $20^{\prime}$; Longitude (E) $\left.79^{\circ} 95^{\prime}\right)$ ] coast of the Bay of Bengal, India. The actinobacteria was isolated using the ISP no. 2 media supplemented with $25 \%$ sea water, $25 \%$ soil extract, cycloheximide (25 mg $\mathrm{mL}^{-1}$ ) and nalidixic acid $\left(25 \mathrm{mg} \mathrm{mL}^{-1}\right.$ ) (Himedia, Mumbai, India) with $9 \% \mathrm{NaCl}$ concentration. Plates were incubated at $28 \pm 2{ }^{\circ} \mathrm{C}$ for 15 days. The isolate was subcultured and maintained in slant culture at $4^{\circ} \mathrm{C}$ as well as at $20 \%$ (v/v) glycerol stock at $-80^{\circ} \mathrm{C}$.

Optimization of media and cultural conditions: To determine the optimal nutritional and cultural conditions and to identify the suitable media for growth, the isolate was inoculated in different culture medias (SCA, ISP 2, ISP 5, ISP 6, ISP 7, Czapek's agar, modified Bennett's agar, glucose/peptone, glycerol/calcium malate agar (Waksman medium No.7) and nutrient agar) and the growth was investigated. The effect of cultural conditions like different incubation temperatures $\left(15,28,37\right.$ and $\left.50^{\circ} \mathrm{C}\right)$, different $\mathrm{pH}(5.0$, 6.0, 7.6 and 9.0) and $\mathrm{NaCl}$ concentrations (1, 3, 6, 12, $15,18,22,24$ and $26 \%$ ) on the growth of the isolate was also studied. The characteristics of physiological, biochemical and concentration of carbon and nitrogen sources were determined as described by ${ }^{[11]}$. After incubation the dry weight of the mycelium was measured and correlated with the growth of the isolate. Based on the growth of the isolate in different media the cultural conditions were optimized.

Taxonomy: The morphological, cultural, physiological and biochemical characterization of the isolate was carried out as described in International Streptomyces Project (ISP) ${ }^{[12]}$. The morphological properties of the isolate were examined by using light microscope as well as scanning electron microscope (Hitachi, S$3400 \mathrm{~N})$. The cell wall fraction and sugar composition were analyzed as per the procedures described 
earlier ${ }^{[13,14]}$. The whole-cell sugar composition was determined as reported by Becker et al. ${ }^{[15]}$ and Lechevalier and Lechevalier ${ }^{[16]}$. Polar lipids were examined and identified using the method of Minnikin et al. ${ }^{[17]}$. Menaquinones were determined as described by Collins ${ }^{[18]}$. The isolate was inoculated in TSB agar plates [trypticase soy broth (BBL), 3\% (w/v); Bacto agar (Difco), 1.5\% (w/v)], incubated for 7 days at $28^{\circ} \mathrm{C}$ and used for fatty acid analysis. The fatty acids were extracted, methylated and analysed using the standard MIDI (Microbial Identification) system ${ }^{[19,20]}$.

The DNA was isolated by HiPurA bacterial DNA isolation and purification kit (Himedia, India) and amplified by PCR using a master mix kit, Medoxmix (Medox, India) as per user manual. The primers and the PCR conditions were adapted from Rainey et al. ${ }^{[21]}$. The design of the sequencing primers and the methodology for the sequencing were adapted from previous reports ${ }^{[21-23]}$. The $1273 \mathrm{bp}$ fragment of the $16 \mathrm{~S}$ rRNA gene of the strain was sequenced in both the sense and antisense directions. The $16 \mathrm{~S}$ rRNA sequence was analyzed for the similarity and homology with the existing sequences available in the data bank of National Center for Biotechnology Information (NCBI) using BLAST search. The DNA sequences were aligned and phylogenetic tree was constructed by neighbor joining method using ClustalW software ${ }^{[24]}$. A bootstrap analysis of 1000 replicates was carried out. The phylogenetic tree based on Maximum-parsimony method was also carried out using MEGA version $3.1^{[25]}$. To determine the $\mathrm{G}+\mathrm{C}$ content, the DNA was isolated by the method of Marmur ${ }^{[26]}$ and the $\mathrm{G}+\mathrm{C}$ content was determined using the thermal denaturation method of Marmur and Doty ${ }^{[27]}$.

Fermentation and extraction of secondary metabolites: Well grown slant cultures of the isolate optimized in production medium were inoculated into $50 \mathrm{~mL}$ medium in $250 \mathrm{~mL}$ Erlenmeyer flasks containing the optimized production medium with sea water $25 \%$, distilled water $75 \%$, pH 7.2 and incubated for 2 days in rotary shaker $(200 \mathrm{rpm})$ at $28^{\circ} \mathrm{C}$. The inoculums $(10 \%)$ were transferred into $200 \mathrm{~mL}$ production medium in $1 \mathrm{~L}$ Erlenmeyer flasks. The inoculated cultures in the production medium were incubated for $72 \mathrm{~h}$ on a rotary shaker $(200 \mathrm{rpm})$ at $28^{\circ} \mathrm{C}$. After fermentation the broth was centrifuged at $4000 \mathrm{rpm}$ for $10 \mathrm{~min}$ at $10^{\circ} \mathrm{C}$ and the filtrate was separated. The supernatant was extracted twice with ethyl acetate $(400 \mathrm{~mL})$ and washed with $500 \mathrm{~mL}$ water. The extract was then concentrated in rotary vacuum and lyophilized using a freeze drier (Thermo, USA) at $5^{\circ} \mathrm{C}$ for $5 \mathrm{~h}$.
Preparation of stock solution: The lyophilized ethyl acetate extract was used to prepare stock using distilled water $\left(1 \mathrm{mg} \mathrm{mL}^{-1}\right)$ and filtered through $0.2 \mathrm{~m}$ filter (Sartorius, India) to avoid contamination. The appropriate concentration of the extract was made by serial dilution.

Bacterial and fungal pathogens: The following bacterial strains Staphylococcus aureus (ATCC 25923), Bacillus subtilis (ATCC 6633), Escherichia coli (ATCC 25922), Klebsiella pneumoniae (ATCC 10273) and fungal strains Candida albicans (ATCC 10231), Aspergillus niger (ATCC No 16404), Aspergillus fumigatus (ATCC No 46645) were used in this study.

In vitro antibacterial assay: The antibacterial activity of crude extract $\left(25 \mathrm{mg} \mathrm{mL}{ }^{-1}\right.$ ) was tested by agar diffusion assay ${ }^{[28]}$. The plates were incubated at $37^{\circ} \mathrm{C}$ for $24 \mathrm{~h}$ during which activity was evidenced by the presence of a zone of inhibition surrounding the well. Each test was repeated three times and the antibacterial activity was expressed as the mean of diameter of the inhibition zones $(\mathrm{mm})$ produced by the secondary metabolite when compared to the controls. Chloramphenicol was used as positive control.

In vitro antifungal assay: Antifungal activity of the crude extract was determined by using the standard method CLSI M38-A (formerly NCCLS) ${ }^{[29]}$. The fungal cultures were maintained in $0.2 \%$ dextrose medium and the optical density 0.10 at $530 \mathrm{~nm}$ was adjusted using spectrophotometer. Each fungal inoculums were applied on plate and evenly spread on Sabouraud's Dextrose agar (HiMedia, India) using a sterile swab. Agar diffusion assay was followed to evaluate the antimicrobial activity along with amphotericin $\mathrm{B}$. The Petri plates were incubated at $30^{\circ} \mathrm{C}$ for 2 days. At the end of the $48 \mathrm{~h}$, inhibition zones formed in the medium were measured in millimeters $(\mathrm{mm})$. All experiments were done in three replicates.

Minimum Inhibitory Concentration (MIC): MIC was determined by the broth 2-fold macro dilution method $^{[30]}$. The crude extract was serially diluted in Mueller Hinton broth for bacteria and Sabouraud's dextrose broth for fungi. Varying concentrations of the extracts $1,500-5 \mathrm{mg} \mathrm{L}^{-1}$ for bacteria and 2,800-5 $\mathrm{mg} \mathrm{L}^{-1}$ for fungi were prepared from the stock solution. $0.1 \mathrm{~mL}$ of the culture was added to the broth each containing the crude extracts. The tubes were incubated aerobically at $37^{\circ} \mathrm{C}$ for $24 \mathrm{~h}$ for bacteria and $30^{\circ} \mathrm{C}$ for $48 \mathrm{~h}$ for fungi. Positive controls were prepared separately for 
both bacteria and fungi with respective organisms in the same culture media without the extract. After incubation, the tube with least concentration of extract shows no growth was taken as the MIC value for the respective organism.

In vitro hemolytic assay: The hemolytic activity of the crude extract on erythrocytes was tested by using the washed erythrocytes (RBCs) from mouse ${ }^{[31]}$ under in vitro conditions in 96-well plates. Each well received $100 \mathrm{~mL}$ of $0.85 \% \mathrm{NaCl}$ solution containing $10 \mathrm{mM}$ $\mathrm{CaCl}_{2}$. The first well served as negative control contained only water and in the second well, $100 \mathrm{~mL}$ of crude extract of various concentrations (5$500 \mathrm{mg} \mathrm{mL}^{-1}$ ) were added. The last well served as positive control containing $20 \mathrm{~mL}$ of $0.1 \%$ Triton $\mathrm{X}$ 100 in $0.85 \%$ saline. Then, each well received $100 \mathrm{~mL}$ of a $2 \%$ suspension of mouse erythrocytes in $0.85 \%$ saline containing $10 \mathrm{mM} \mathrm{CaCl}$. After 30 min incubation at room temperature, centrifuged and the supernatant was used to measure the absorbance of the liberated hemoglobin at $540 \mathrm{~nm}$. The average value was calculated from triplicate assay.

Cell culture: HeLa cell lines were obtained from ATCC and maintained in DMEM (Himedia, Mumbai, India) medium supplemented with $10 \% \mathrm{FBS}(\mathrm{v} / \mathrm{v})$ and $100 \mathrm{mg} \mathrm{L}^{-1}$ streptomycin and $100 \mathrm{IU} \mathrm{mL}^{-1}$ penicillin (Himedia, India) at $37^{\circ} \mathrm{C}$ in a $\mathrm{CO}_{2}$ incubator with $5 \%$ carbon dioxide.

MTT cell proliferation assay: The cytotoxic activity of the crude extract (diluted in DMSO 0 to $100 \mu \mathrm{g} \mathrm{mL}^{-1}$ ) on HeLa cells $\left(1 \times 10^{5}\right.$ cells/well) were tested by using the CellQuanti-MTT cell viability assay kit (Bioassay Systems). The wells with only culture medium or cells treated with $0.1 \%$ of DMSO served as control. The graph was plotted with cell viability against the time period in hours at increasing concentrations of secondary metabolite. The mean and the $\mathrm{IC}_{50}$ value were calculated by non-linear regression analysis using the data analysis software (prism) from three independent experiments.

\section{RESULTS}

The isolated strain is Gram +ve, non-motile and aerobic bacteria. The aerial mycelium is straight, segmented, 0.6-1.0 mm, white in color. The diameter of cells is $1.2 \times 0.5 \mathrm{~mm}$. The spores are rough arranged in straight to loosely spiral shape and non-motile (Fig. 1). Extensively fragmented substrate mycelia were observed under light and scanning electron microscopy (Fig. 2). Sporangia, flagellated spores and sclerotia were not observed. The cultural, biochemical and physiological characteristics of the isolate is given in Table 1.

Table 1: The cultural, biochemical and physiological characters of Saccharopolyspora salina VITSDK4

\begin{tabular}{|c|c|}
\hline Tests & Results \\
\hline Grams stain & + \\
\hline Diameter of cells ( $\square \mathrm{m})$ & $1.2 \times 0.5$ \\
\hline Colony pigmentation & brown \\
\hline Aerial mycelium & White \\
\hline Substrate mycelium & Grey \\
\hline Motility & - \\
\hline Colony color & White \\
\hline Spores & Rough \\
\hline Spore arrangement & straight to loose spirals \\
\hline Starch hydrolysis & + \\
\hline Nitrate reduction & + \\
\hline Gelatin liquefactions & + \\
\hline Milk coagulation & - \\
\hline Melanin production & - \\
\hline Hemolysis on blood agar & + \\
\hline $\mathrm{H}_{2} \mathrm{~S}$ & - \\
\hline \multicolumn{2}{|l|}{ Carbon source $(1 \% \mathrm{w} / \mathrm{v})^{*}$} \\
\hline D-glucose & + \\
\hline Starch & + \\
\hline Sucrose & + \\
\hline D-xylose & + \\
\hline D-galactose & + \\
\hline Maltose & + \\
\hline L-arabinose & + \\
\hline Lactose & + \\
\hline Inositol & + \\
\hline Glycerol & - \\
\hline \multicolumn{2}{|l|}{ Nitrogen Source $(1 \%$ w/v)* } \\
\hline Peptone & + \\
\hline Yeast extract & + \\
\hline Casein & + \\
\hline Ammonium sulphate & + \\
\hline Ammonium nitrate & + \\
\hline Ammonium citrate & + \\
\hline Potassium nitrate & + \\
\hline Sodium nitrate & + \\
\hline Sodium acetate & + \\
\hline Sodium citrate & + \\
\hline Urea & + \\
\hline \multicolumn{2}{|c|}{ Temperature for growth $\left({ }^{\circ} \mathrm{C}\right)^{*}$} \\
\hline Range & $20-40$ \\
\hline Optimum & 28 \\
\hline \multicolumn{2}{|l|}{ pH for growth* } \\
\hline Range & $6.0-8.5$ \\
\hline Optimum & 7.6 \\
\hline \multicolumn{2}{|c|}{ Effect of $\mathrm{NaCL}$ concentration $(\mathrm{w} / \mathrm{v})^{*}$} \\
\hline 8 & + \\
\hline $12 \%$ & + \\
\hline $18 \%$ & + \\
\hline $22 \%$ & - \\
\hline $24 \%$ & - \\
\hline \multicolumn{2}{|l|}{ Chemical characteristics } \\
\hline Cell wall amino acids & meso-DAP \\
\hline Phospholipids & Type III \\
\hline Predominant menaquinone & MK-9 $\left(\mathrm{H}_{4}\right)$ \\
\hline Fatty acid & iso- $\mathrm{C}_{15: 0}$, iso- $\mathrm{C}_{16: 0}$ \\
\hline $\mathrm{G}+\mathrm{C}$ content $(\mathrm{mol} \%)$ & 68.2 \\
\hline
\end{tabular}




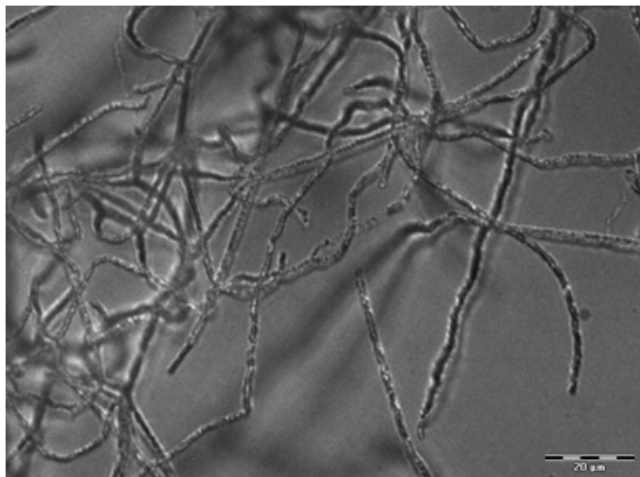

Fig. 1: Phase-contrast micrograph of Saccharopolyspora salina VITSDK4 showing mature hyphae. Bar $1 \mu \mathrm{m}$

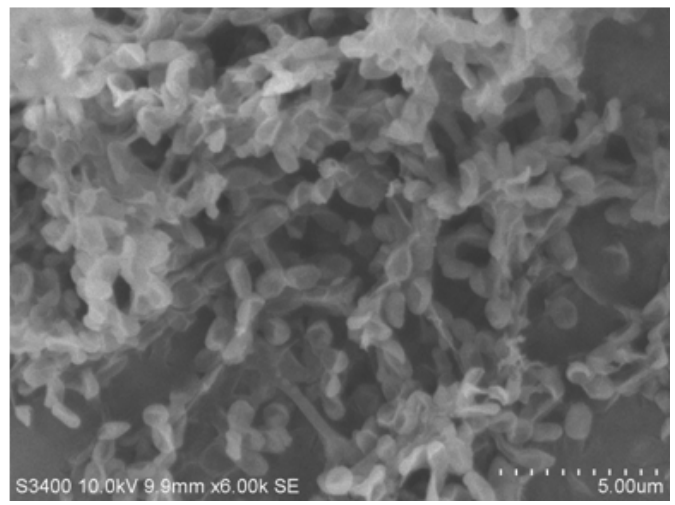

Fig. 2: Scanning electron micrograph of Saccharopolyspora salina VITSDK4 grown in optimized medium $(9 \% \mathrm{NaCl}(\mathrm{w} / \mathrm{v}), \mathrm{pH} 7.6)$ at $28^{\circ} \mathrm{C}$ for 6 days. The bar represents $5 \mu \mathrm{m}$

Diaminopimelic acid (DAP) analysis shows the presence of meso-DAP in the cell wall peptidoglycan indicating that it belongs to cell wall type-IV. Arabinose and galactose were detected in whole cell hydrolysates. The predominant menaquinone is MK$9\left(\mathrm{H}_{4}\right)$. The typical polar lipids are diphosphatidylglycerol, phosphatidylcholine, phosphatidylglycerol and phosphatidylinositol. (phospholipids type III sensu Lechevalier et al. ${ }^{[16]}$ ). The fatty acid profile comprised mainly of saturated straight-chain and iso-and anteiso-branched-chain fatty acids. The major fatty acids are iso- $\mathrm{C}_{15: 0}$, iso$\mathrm{C}_{\text {16:0 }}$, iso- $\mathrm{C}_{17: 0}$, anteiso- $\mathrm{C}_{16: 0}$ and anteiso- $\mathrm{C}_{17: 0}$. The $\mathrm{G}+\mathrm{C}$ content of the DNA isolated from the species is $68.2 \mathrm{~mol} \%$. The chemical and morphological properties of the isolate resembles with the genus Saccharopolyspora.

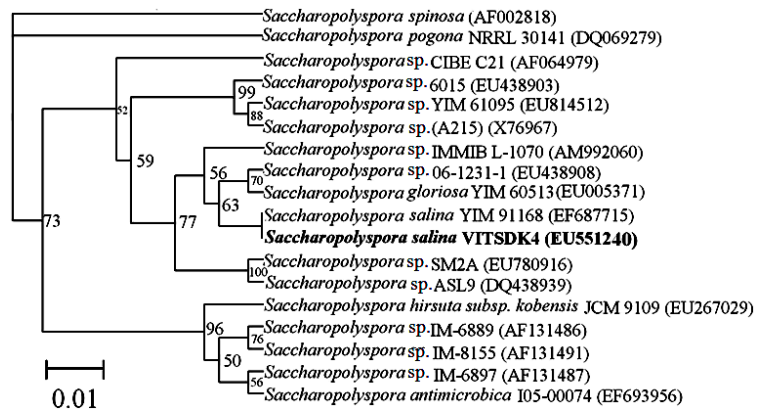

Fig. 3: The phylogram showing the position of Saccharopolyspora salina VITSDK4 with other Saccharopolyspora based on 16S rRNA gene sequence. Phylogenetic tree based on neighbor joining analysis of 1000 resampled data. Number at nodes indicates the percent level of bootstrap support. Score bar represents 1 nucleotide substitution per 100 nucleotides. Bootstrap values of 50 and above only are shown

A BLAST search of the $1273 \mathrm{bp}$ 16S-rRNA gene sequence of the isolate showed $100 \%$ homology to Saccharopolyspora salina. The phylogenetic tree was constructed based on neighbor joining method shows that the isolate is most closely related to Saccharopolyspora salina which is also supported by the high boot strap value. Based on the molecular taxonomy and phylogeny the isolate was identified as Saccharopolyspora salina and designated as Saccharopolyspora salina VITSDK4. The 16S rRNA sequence of Saccharopolyspora salina VITSDK4 has been deposited in the GenBank (NCBI, USA) under the accession number EU551240. A neighbor-joining tree based on 16S rRNA gene sequences showed that the isolate shares a same clade with Saccharopolyspora salina and occupies a distinct phylogenetic position within the radiation including representatives of the family Saccharopolyspora (Fig. 3).

The optimal growth of the isolate was attained in the production medium when cultivated at temperature $28^{\circ} \mathrm{C} ; \mathrm{pH}$ 7.6. The growth was also analyzed with different organic and inorganic nitrogen sources. Both organic and inorganic sources support the growth but organic nitrogen sources produce abundant colonies and sporulation. Among carbon sources, Dglucose, starch, sucrose, D-xylose, D-galactose, maltose, L-arabinose, lactose, inositol were utilized for growth, but glycerol was not utilized. The isolate grows well between 6-18\% $\mathrm{NaCl}$ concentrations with the optimal concentration of $9 \%$ and no growth was observed at 0 and $22 \%$ salt concentration. 
Am. J. Infect. Dis., 5 (2): 90-98, 2009

Table 2: The antibacterial and antifungal activity of ethyl acetate extract of Saccharopolyspora salina VITSDK4

\begin{tabular}{lll}
\hline Microorganism & Zone of inhibition $(\mathrm{mm})$ & $\mathrm{MIC}\left(\mu \mathrm{g} \mathrm{mL} \mathrm{m}^{-1}\right)$ \\
\hline Escherichia coli & $13.6(20.5)$ & $174(3.16)$ \\
Klebsiella pneumoniae & $16.0(18.5)$ & $126(28)$ \\
Staphylococcus aureus & $8.4(19.8)$ & $>1000(11.9)$ \\
Bacillus subtilis & $5.1(22.1)$ & $>1000(24.8)$ \\
Aspergillus niger & $15.9(21.4)$ & $96.5(23.8)$ \\
Aspergillus fumigatus & $13.3(19.5)$ & $108.5(20.5)$ \\
Candida albicans & $8.5(11.6)$ & $21.0(30.2)$ \\
\hline
\end{tabular}

The zone of inhibition and MIC for the standard antibiotics is given within parenthesis. Chloramphenicol and Amphotericin B are the standards for bacteria and fungi respectively

Based on the results of physiological test the medium has been designed for the optimum growth which contains glucose $0.5 \%$, soluble starch $2 \%$, meet extract $0.4 \%$, yeast extract $0.5 \%$, peptone $0.5 \%$, calcium carbonate $0.4 \%$, sodium sulfate $0.1 \%$, potassium chloride $0.05 \%$, magnesium chloride $0.2 \%$, dipotassium phosphate $0.05 \%$, sodium chloride $12 \%, \mathrm{pH} 7.6$.

The antimicrobial activity of ethyl acetate extract of the isolate is shown in Table 2. The maximal activity was observed against Klebsiella pneumoniae with the MIC value of $126 \mathrm{mg} \mathrm{mL}^{-1}$ when compared to chloramphenicol $\left(26 \mathrm{mg} \mathrm{mL} \mathrm{m}^{-1}\right)$. The other bacterial pathogens susceptible to the crude extract are E. coli (MIC of $174 \mathrm{mg} \mathrm{mL}^{-1}$ and $13.6 \mathrm{~mm}$ zone of inhibition), S.aureus $(8.4 \mathrm{~mm})$ and B.subtilis $(5.1 \mathrm{~mm})$. It crude extract also exhibits a good antagonistic activity against A.niger, A.flavus and C.albicans. The zone of inhibition is $15.9,13.3$ and $8.5 \mathrm{~mm}$ and the MIC is $96.5,108.5$ and $52 \mathrm{mg} \mathrm{mL}$ respectively. Among the fungal pathogens C.albicans was more susceptible to the extract when compared amphotericin B. The effect of crude extract on cytotoxicity on HeLa cells showed a concentration and time dependent activity. The $\mathrm{IC}_{50}$ value against $\mathrm{HeLa}$ cells was found to be $26.2 \mathrm{mg} \mathrm{mL}^{-1}$. At $40 \mathrm{mg} \mathrm{mL}^{-1}$ concentration more than $70 \%$ cell death was observed. The hemolytic activity on erythrocytes showed $\mathrm{IC}_{50}$ value of $266 \mathrm{mg} \mathrm{mL}^{-1}$. The results suggest that the crude extract is less toxic to normal cells and toxic to He La cells.

\section{DISCUSSION}

The marine microorganisms are known to be rich sources of novel compounds; to date about 1000 natural products were derived from marine microbes. Interestingly marine actinomycetes produce many pharmacologically potential compounds with antibiotic and antitumor properties. Actinobacteria have been proven as a potential source of bioactive compounds and richest source of secondary metabolites. They are the most economically and biotechnologically valuable prokaryotes. However, the research on marine Actinobacteria from Indian peninsula is very scanty. In the present study we have demonstrated that our isolated halophilic Saccharopolyspora salina VITSDK4 produces a extracellular compound and inhibit the growth of tumor cells as well as microbial cells.

Our sampling site Marakkanam is situated in southern coast of India within Tamil Nadu province. It is a narrow sandy coastal belt exhibits tidal flats and marsh zones. It is perched at a height of 14 meters (45 feet) above mean sea level and has large areas of salt pans near wide backwater with salinity of 32-38 parts per thousand. In the course of our systematic screening for bioactive marine actinobacteria, 116 strains were isolated and only 7 isolates showed broad spectrum activity. The majority of the isolated strains were belongs to Streptomyces, some were belongs to Micromonospora, Actinopolyspora and few belongs to other types. The strain VITSDK4 with significant antitumor and antimicrobial activity was further identified as Saccharopolyspora salina. The cultural, morphological, biochemical, physiological characteristics indicates that the strain belongs to the genus Saccharopolyspora. Chemotaxonomic properties are typical to the genus Saccharopolyspora. It is evident from the phylogenetic analysis that the strain VITSDK4 closely matches with the strain Saccharopolyspora salina. The strain shows 100\% similarity with Saccharopolyspora salina. A tree constructed by the neighbor joining method shows the distinct phyletic line which is closesly related with Saccharopolyspora salina. The strain is sensitive to, rifampicin and lincomycin, but resistant to neomycin and penicillin $\mathrm{G}$.

Optimization of media and cultural conditions were carried out by a systematic study. Various carbon and nitrogen sources were supplemented and the growth was measured as dry weight of the mycelium. Glucose, xylose and starch serves as sole carbon source and better growth was seen if yeast extract is used as a sole nitrogen source and poor growth was seen when inorganic nitrogen source was used. As the samples were collected from the ocean near-salt pans, the salt concentration in the media was increased and the growth was evaluated. The organism requires salt concentration of $9 \%$ for growth and at low concentrations no growth was observed. At the concentrations of less than $3 \%(\mathrm{w} / \mathrm{v})$ the colonies appear as plaque like holes. The salt requirement suggests that the organism is moderately halophilic. The sediment sample collected for the isolation of this organism was from the shore where many salt pans exist. The organism tends to grow and sporulate even at 
$12 \%$ salt concentration, but it exhibits very slow growth which takes 10-15 days. This suggests that the organisms ability to grow and multiply in the marine environment at various salt concentrations.

Halophilic microorganisms can be conveniently grouped according to $\mathrm{NaCl}$ requirements for growth ${ }^{[32]}$. Extreme halophiles are able to grow in saturated $\mathrm{NaCl}$ and unable to grow in the presence of $\mathrm{NaCl}$ concentrations less than $12 \%$. Larsen $^{[33]}$ defined moderate halophiles as organisms growing optimally between 5 and $20 \% \mathrm{NaCl}$. Since our isolate also showed similar $\mathrm{NaCl}$ requirements for their growth; the strain is considered as halophiles and absence of $\mathrm{NaCl}$ in the medium inhibits their growth. Thus VITSDK4 phylogenetically distinct and exhibited different physiological characteristics from other Streptomyces described. Apart from sodium chloride, addition of potassium chloride 6-20\%) and magnesium chloride (6$22 \%$ ) also enhances the growth with maximal growth at $16 \%$ for $\mathrm{KCl}$ and $18 \%$ for $\mathrm{MgCl}_{2} \cdot 6 \mathrm{H}_{2} \mathrm{O}$.

Five liter of the fermentation broth yield $786 \mathrm{mg}$ of crude extract. The extract was dissolved in DMSO ( $1 \mathrm{mg} \mathrm{mL}^{-1}$ ) and made as the stock for the assessment of cytotoxic properties. The DMSO control was maintained for the assays and results were calculated. The extract showed a strong growth inhibition against HeLa cells with an $\mathrm{IC}_{50}$ of $26.2 \mathrm{mg} \mathrm{mL}^{-1}$, which is significant with control. The $\mathrm{IC}_{50}$ against mouse erythrocytes was found to be $266 \mathrm{mg} \mathrm{mL}^{-1}$ which shows that the cytotoxicity on $\mathrm{HeLa}$ cells was not related to membrane integrity. Also, notable activity was seen against fungal and Gram positive pathogens, but the activity against Gram negative microbes was less. Previously we have reported a Streptomyces strain with moderate hemolytic and antimicrobial activity isolated from Marakkanam coast ${ }^{[34]}$. The cytotoxic activity of VITSDK4 on HeLa cells suggests that the strain could be clinically important and need to be investigated further for the anticancer properties.

\section{CONCLUSION}

Our results indicate that the isolated Saccharopolyspora salina is a moderately halophilic strain which exhibits significant cytotoxic and strong antibiosis against fungal and Gram negative pathogens. Further studies on the purification and characterization of bioactive compounds from the strain are underway. Most of the studies conducted in Indian peninsula have been restricted to isolation, identification and studied for their antagonistic properties against different microbial pathogens. But the detailed studies on the bioactive compounds from the marine actinomycetes are lacking. It is suggested that the frequent and systematic screening of marine actinomycetes in the Indian peninsula could provide novel species as well as novel bioactive compounds.

\section{ACKNOWLEDGEMENT}

The researchers wish to thank the management of VIT University for providing necessary facilities for the completion of this study and KS thankful to the VIT management for the award of TRA. Researchers are also thankful to Mr.Elumalai, Pondicherry University, for SEM photographs.

\section{REFERENCES}

1. Kelecom, A., 2002. Secondary metabolites from marine microorganisms. AnAcad. Bras. Cienc., 74: $151-170$. DOI: 10.1590 S000137652002000100012

2. Jensen, P.R. and W. Fenical, 2000. Marine Microorganisms and Drug Discovery: Current Status and Future Potential. In: Drugs from the Sea, N. Fusetani (Ed.). Karger, Basel, pp: 6-29.

3. Bernan, V.S., M. Greenstein and W.M. Maise, 1997. Marine microorganisms as a source of new natural products. Adv. Applied Microbiol., 43: 57-90. DOI: 10.1016/S0065-2164(08)70223-5

4. Newman, D.J. and M.G. Cragg, 2007. natural products as sources of new drugs over the last 25 years. J. Nat. Prod., 70: 461-477. DOI: $10.1021 / \mathrm{np} 068054 \mathrm{v}$

5. Kelecom, A, 1999. Chemistry of marine natural products: Yesterday, today and tomorrow. AnAcad. Bras. Cienc., 71: 249-263. DOI: 684.5400008394380.0110

6. Moron, R., I. Gonzalez and O. Genilloud, 1999. New genus-specific primers for the PCR identification of members of the genera pseudonocardia and saccharopolyspora. Int. J. Syst. Evol. Microbiol., 49: 149-162. DOI: 10.1099/00207713-49-1-149

7. Lacey, J. and M. Goodfellow, 1975. A novel actinomycete from sugar cane bagasse: Saccharopolyspora hirsuta gen. et sp. nov. J. Gen. Microbiol., 88: 75-85. http://ipvgen.unipv.it/ biblio/journal_general_micr obiology.html

8. Lu, Z., Z. Liu, L. Wang, Y. Zhang, W. Qi and M. Goodfellow, 2001. Saccharopolyspora flava sp. nov. and Saccharopolyspora thermophila sp. nov., novel actinomycetes from soil. Int. J. Syst. Evol. Microbiol., 51: 319-325. http://ijs.sgmjournals.org/cgi/reprint/51/2/319 
9. Goodfellow, M., J. Lacey, M. Athalye, T.M. Embley and T. Bowen, 1989. S. gregorii and Saccharopolyspora hordei: Two new actinomycete species from fodder. J. Gen. Microbiol., 135: 2125-2139. http://mic.sgmjournals.org/cgi/reprint/135/8/2125

10. Embley, T.M., 1992. The family Pseudonocardiaceae. In: The Prokaryotes, Balows, A., H.G. Trüper, M. Dworkin, W. Harder and K.H. Schleifer (Eds.). Springer, Berlin, pp: 996-1027.

11. Gordon, R.E., D.A. Barnett, J.E. Handerhan and C.H.N. Pang, 1974. Nocardia coeliaca, Nocardia autotrophica and the nocardin strain. Int. J. Syst. Bacteriol., 24: 54-63. DOI 10.1099/00207713-24$1-54$

12. Shirling, E.B. and D. Gottlieb, 1966. Methods for characterization of Streptomyces species. Int. J. Syst. Bacteriol., 16: 312-340. DOI: 10.1099/00207713-16-3-313

13. Lechevalier, M.P. and H.A. Lechevalier, 1980. The Chemotaxonomy of Actinomycetes. In: Actinomycete Taxonomy, Society for Industrial Microbiology, Dietz, X. and Y. Thayer (Eds.). Arlington, VA., pp: 227-291.

14. Hasegawa, T., M. Takizawa and S. Tanida, 1983. A rapid analysis for chemical grouping of aerobic actinomycetes. J. Gen. Applied Microbiol., 29: 319-322. DOI: 10.2323/jgam.29.319

15. Becker, B., M.P. Lechevalier and H.A. Lechevalier, 1965. Chemical composition of cell-wall preparations from strains of various form genera of aerobic actinomycetes. Applied Microbiol., 13: 236-243.

http://www.pubmedcentral.nih.gov/articlerender.fc gi? artid $=1058228$

16. Lechevalier, M.P., C. De Bievre and H.A. Lechevalier, 1977. Chemotaxonomy of aerobic actinomycetes: Phospholipid composition. Biochem. Syst. Ecol., 5: 249-260.

http://www.springerlink.com/index/0DQ0ND8CA YDU9BA2.pdf

17. Minnikin, D.E., A.G.O’Donnell, M. Goodfellow, G. Alderson, M. Athalye, A. Schaal and J.H. Parlett, 1984. An integrated procedure for the extraction of isoprenoid quinones and polar lipids. J. Microbiol. Methods, 2: 233-241. DOI: 10.1016/01677012(84)90018-6

18. Collins, M.D., 1985. Isoprenoid Quinone Analysis in Classification and Identification. In: Chemical Methods in Bacterial Systematics, Goodfellow, M. and D.E. Minnikin (Eds.). Acdemic Press, London, pp: 267-287.
19. Sasser, M., 1990. Identification of bacteria by gas chromatography of cellular fatty acids. Newark, DE, MIDITechnical. $\quad$ Note. 101. http://www.microbialid.com/PDF/TechNote_101.pdf

20. Kampfer, P. and R.M. Kroppenstedt, 1996. Numerical analysis of fatty acid patterns of coryneform bacteria and related taxa. Can. J. Microbiol., 42: 989-1005. DOI: 10.1139/m96-128

21. Rainey, F.A., N.L.Ward-Rainey, R.M. Kroppenstedt and E. Stackebrandt, 1996. The genus Norcardiopsis represents a phylogenetically coherent taxon and a distinct Actinomycete lineage: Proposal of Nocaridiopsaceae fam. Int. J. Syst. Bacteriol., 46: 1088-1092. DOI: 10.1099/00207713-46-4-1088

22. Mincer, T.J., P.R. Jensen, C.A. Kauffman and W. Fenical, 2002. Widespread and persistent populations of a major new marine Actinomycete taxon in ocean sediments. Applied Environ. Microbiol., 68: 5005-5011. DOI: 10.1128/AEM.68.10.5005-5011.2002

23. Nathan, A., Magarvey, J.M. Keller, V. Bernan, M. Dworkin and D.H. Sherman, 2004. Isolation and characterization of novel marine-derived actinomycete taxa rich in bioactive metabolites. Applied Environ. Microbiol., 70: 7520-7529. DOI: 10.1128/AEM.70.12.7520-7529.2004

24. Saitou, N. and M. Nei, 1987. The neighbor-joining method: a new method for reconstructing phylogenetic trees. Mol. Biol. Evol., 24: 189-204. http://mbe.oxfordjournals.org/cgi/reprint/4/4/406

25. Kumar, S., K. Tamura, I.B. Jakobsen and M. Nei, 2001. MEGA2: Molecular evolutionary genetics analysis software. Bioinformatics, 17: 1244-1245. http://bioinformatics.oxfordjournals.org/cgi/content /abstract/17/12/1244

26. Marmur, J., 1961. A procedure for the isolation of deoxyribonucleic acid from microorganisms. J. Mol. Biol. 3: 208-218.

http://garfield.library.upenn.edu/classics1991/A199 1GB94800002.pdf

27. Marmur, J. and P. Doty, 1962. Determination of the base composition of deoxyribonucleic acid from its thermal denaturation temperature. J. Mol. Biol. 5: 109-118. http://www.ncbi.nlm.nih.gov/pubmed/14470099

28. Barry, A.L. and C. Thornsberry, 1985. Susceptibility Tests: Diffusion test procedure. In: Manual of Clinical Microbiology, 4th Edn., Ballows, E.A., W.J. Hawsler Jr and H.I. Shadomy (Eds.). American Society of Microbiology, Washington DC., pp: 978-987. 
29. Wayne, P.A., 2002. National Committee for Clinical Laboratory Standards. Reference method for broth dilution antifungal susceptibility testing of filamentous fungi. Approved standard M38-A. http://www.clsi.org/source/orders/free/M27-S3.pdf

30. Andrews, J.M., 2001. Determination of minimal inhibitory concentrations. J. Antimicrob. Chemother., 48: 5-16.

http://jac.oxfordjournals.org/cgi/content/short/48/s uppl_1/5

31. Malagoli, 2007. A full-length protocol to test hemolytic activity of palytoxin on human erythrocytes D. Invertebrate Surviv. J., 4: 92-94. http://www.isj.unimo.it/articoli/ISJ141.pdf
32. Ventosa, A., Nieto J.J., Oren. A., 1998. Biology of moderately halophilic aerobic bacteria. Microbiol. Mol. Biol. Rev., 62: 504-544. DOI: 10922172/98/\$04.00+0

33. Larsen, H., 1986. Halophilic and halotolerant microorganisms: An overview and historical perspective. FEMS Microbiol. Rev., 39: 3-7. DOI: 10.1111/j.1574-6968.1986.tb01835.x

34. Suthindhiran, K., Kannabiran, K., 2009. Hemolytic activity of Streptomyces VITSDK1 spp. isolated from marine sediments in Southern India. J. Mycol. Méd., 19 : 1-70. DOI: 10.1016/j.mycmed.2009.01.001 